\title{
A study on Customer Satisfaction of Public Sector Bank's Mobile Application with reference to Coimbatore City
}

\author{
V. Santhi ${ }^{1}$ \\ \{ firdaussudheer@gmail.com ${ }^{1}$ \} \\ Head of the Department, Department of Humanities, PSG College of Technology, Coimbatore, \\ Tamilnadu ${ }^{1}$
}

\begin{abstract}
Technological advancement helps the people to reach their task from home with less cost. People from the entire field may use this advancement, network service providers and device much support for it. Now $4 \mathrm{G}$ network provides more speed and the mobile handset also more speed and storage, it all support the technological advancement. Convenient sampling method to collect data. Researcher had google sheet for data collection, shared the link after had discussion with the sample respondents. Google sheet linked shared only with the individuals with confirmation, not shared in any WhatsApp group. Twenty-five questionnaires were printed and distributed directly the respondents and two hundred digital questionnaires distributed through WhatsApp. Out of that 23 hard questionnaire and out of two hundred digital questionnaires, 194 were filled by the sample respondents. Finally, 217 questionnaires were taken for this study; there is no discrepancy in data analysis about these samples. Objectives of the study are following. Personal details of the respondents have to present, the second will be regarding variable finding and analysis of satisfaction level and third objective is to offer suggestions to the public sector banks to retain the customers and provide the best service. Bank's mobile application is convenient to maintain the credit card outstanding and payment details. The satisfaction of bankers' mobile application is only medium level. Banks may conduct more study periodically to measure the level of utilization and satisfaction to improve the mobile application and satisfy their customers.
\end{abstract}

Keywords: Mobile banking, mobile application, google pay, e-banking.

\section{Introduction}

Technological advancement helps the people to reach their task from home with less cost. People from the entire field may use this advancement, network service providers and device much support for it. Now $4 \mathrm{G}$ network provides more speed and the mobile handset also more speed and storage, it all support the technological advancement. During 2020-2021 pandemic period students and teachers are using internet, electronic devices for their online classes, business people are using google pay for online transfer of funds, even many retailers, and street sellers are using QR code to receive money from customers. The banks support is vital role in this period. All the public sector and private sector banks have developed their ownmobile application to operate their account. Commonly all users were installed google pay 
and using it for all their banking operations, public and private sector banks are advised their customers to use only their own bank application for safe and secure banking operations.

There are twelve public sector banks are function at present in India. i.e. (i) Punjab National Bank, (ii) Indian Bank, (iii) State bank of India, (iv) Canara Bank, (v) Union bank, (vi) Indian overseas bank, (vii) UCO bank, (viii) Bank of Maharashtra, (ix) Punjab and Sind bank, (x) Bank of India, (xi) Central bank of India and (xii) Bank of Baroda.

\section{Review of literature}

Gomachab and Maseke (2018), the factors contributes $75 \%$ of the overall satisfaction namely reliability, convenience, cost effectiveness, available on different mobile networks, advertisements, service and respondents income. The respondents felt that the mobile banking is more secure than the branch based service.

Ali, et. al. (2019), the researchers studied the rating of mobile applications of the banking industry. The banking industries updating their software as well as mobile application according to the technological advancement. According to the customer's requirement and demand, banks are doing it to satisfy the customers. They said more research is needed on the use of rating and reviews into development decision making in the banking industry.

Shukla and Singh (2020), the transformation of mobile banking industry by providing convenience in emerging Indian market to their customers. Smart phone plays pivot role in internet banking service which more convenient to the customers and less cost, the transactions speed with respect to customer satisfaction.

Uwalaka and Eze (2020), in their study they mentioned that, the technology is the primary key for integrated banking facilities, the service quality of the banks improved because of e-banking. Customers are happy in e-banking and their money transfer are also more secure, the conventional banking changed.

The above four reviews presented by the researcher regarding this present study, and extracted their conclusion. All studies said that the technological upgrade helps the ecommerce, e-banking and etc. the level of satisfaction may vary to service provider, customer's perception, customer's income level, customer's usage level and etc. researcher used this research gap to conduct the study in the present study area.

\section{Objectives of the study}

Researcher had developed three objectives i.e. personal details of the respondents have to present, the second will be regarding variable finding and analysis of satisfaction level and third objective is to share the suggestions to the public sector banks to retain the customers and provide the best service.

\section{Sample Design}


All the banks having their own mobile application helps their customers. Researcher conducted the present study in Coimbatore city, used convenient sampling method to collect data. Researcher had google sheet for data collection, shared the link after had discussion with the sample respondents. Google sheet linked shared only with the individuals with confirmation, not shared in any WhatsAppgroup. Twenty-five questionnaires were printed and distributed directly and two hundred digital questionnaires distributed through WhatsApp. Out of that 23 hard questionnaire and out of two hundred digital questionnaires, 194 were filled by the sample respondents. Finally, 217 questionnaires were taken for this study; there is no discrepancy in data analysis about these samples.

\section{Period of the Study}

The study conducted during September 2021. Topic decided during first week of September and data collection were done during that period. Analysis and write up work were completed during third and fourth week of September 2021.

\section{Tools and Techniques}

Researcher has used percentage analysis, which will help to understand the personal details, Likertfive-point scale used to find the satisfaction level and to complete the analysis. Correlation helped to find the relationship of personal details and satisfaction level.

\section{Analysis and Interpretation}

The following table shows the socio economic profile of the sample respondents.

Table-1 Respondent's Age group

\begin{tabular}{|l|l|l|}
\hline Age group & $\begin{array}{l}\text { Number } \\
\text { Respondents }\end{array}$ & of \\
\hline Less than 25 years & 32 & 14.75 \\
\hline $\begin{array}{l}\text { Between 26 years and 40 } \\
\text { years }\end{array}$ & 52 & 23.96 \\
\hline $\begin{array}{l}\text { Between 41 years and 55 } \\
\text { years }\end{array}$ & 78 & 35.94 \\
\hline 55 years and above & 55 & 25.35 \\
\hline & 217 & 100 \\
\hline
\end{tabular}

Sources: Survey data

Thirty-two (14.75\%) respondents are less than 25 years old. Fifty-two $(23.96 \%)$ respondents are 26 years to 40 years old. Seventy-eight $(35.94 \%)$ respondents are 41 years to 55 years old and remaining fifty-five $(25.35 \%)$ respondents are 55 years and above. Majority $(35.94 \%)$ of the respondents are from 41 years to 55 years old.

Table- 2 Respondent's Gender details

\begin{tabular}{|l|l|l|}
\hline Gender & Number of Respondents & \% \\
\hline Male & 133 & 61.29 \\
\hline
\end{tabular}




\begin{tabular}{|l|l|l|}
\hline Female & 84 & 38.71 \\
\hline & 217 & 100 \\
\hline
\end{tabular}

Sources: Survey data

One hundred and thirty-three respondents are male $(61.29 \%)$ and the remaining eighty-four respondents are female $(38.71 \%)$. Majority of the respondents are male $(61.29 \%)$.

Table- 3 Respondent's Marital Status

\begin{tabular}{|l|l|l|}
\hline Marital Status & Number of Respondents & \% \\
\hline Married & 122 & 56.22 \\
\hline Unmarried & 95 & 43.78 \\
\hline & 217 & 100 \\
\hline
\end{tabular}

\section{Sources: Survey data}

One hundred and twenty-two $(56.22 \%)$ respondents are married and remaining ninety-five $(43.78 \%)$ respondents are unmarried. Majority $(56.22 \%)$ of the respondents are married.

Table- 4 Respondent's Family type

\begin{tabular}{|l|l|l|}
\hline Family Type & Number of Respondents & \% \\
\hline Join family type & 74 & 34.10 \\
\hline Nuclear family type & 143 & 65.90 \\
\hline & 217 & 100 \\
\hline
\end{tabular}

Sources: Survey data

Seventy-four $(34.10 \%)$ respondents are joint family type respondents and remaining one hundred and forty-three $(65.90 \%)$ respondents are nuclear family type.

Table - 5 Respondent's Monthly Family Income

\begin{tabular}{|c|l|l|}
\hline $\begin{array}{c}\text { Respondent's Monthly } \\
\text { Family Income }\end{array}$ & Number of Respondents & \% \\
\hline Up Rs. 30,000 & 35 & 16.13 \\
\hline Rs. 30,001 to Rs. 60,000 & 53 & 24.42 \\
\hline Rs. 60,001 to Rs. 90,000 & 86 & 39.63 \\
\hline Above Rs. 90,000 & 43 & 19.82 \\
\hline & 217 & 100 \\
\hline
\end{tabular}

\section{Sources: Survey data}

Thirty-five (16.13\%) respondent's monthly family income is less than to Rs. 30,000 . Fifty-three $(24.42 \%)$ respondent's monthly family income is from Rs. 30,001 to Rs. 60,000. Eighty-six (39.63\%) respondent's monthly family income is from Rs. 60,001 to Rs. 90,000 and remaining forty-three $(19.82 \%)$ respondent's monthly family income is Rs. 90,000 and above. Majority (39.62\%) respondent's monthly family income is between Rs. 60,001 and Rs. 90,000 .

Table - 6 Respondent's Occupation
\begin{tabular}{|l|c|c|}
\hline Respondent's Occupation & Number of Respondents & $\%$ \\
\hline Private Employees & 86 & 39.63 \\
\hline Government employees & 55 & 25.73 \\
\hline Professionals & 45 & 20.73 \\
\hline Retired, house wife and others & 31 & 14.29 \\
\hline & 217 & 100 \\
\hline
\end{tabular}

\section{Sources: Survey data}

Eighty-six $(39.63 \%)$ respondents are working in private companies. Fifty-five $(25.73 \%)$ respondents are working in Government sector. Forty-five $(20.73 \%)$ respondents are 
professionals and remaining thirty-one (14.29\%) respondentsare retired, homemaker and others. Majority (25.73\%) of the respondents are working in Government sector.

Table- 7 Number of Bank account using by the samples

\begin{tabular}{|l|l|l|}
\hline Number of Bank account & Number of Respondents & \% \\
\hline Only one bank account & 43 & 19.81 \\
\hline Two bank account & 118 & 54.38 \\
\hline More than two bank account & 56 & 25.81 \\
\hline & 217 & 100 \\
\hline
\end{tabular}

Sources: Survey data

Forty-three (19.81\%) respondents are having only one bank account with bank's mobile application. One hundred and eighteen (54.38\%) respondents are having two bank account with bank's mobile application and remaining fifty-six $(25.81 \%)$ respondents are having more than two bank account with banks mobile application. Majority $(54.38 \%)$ of the samples are operating two bank account for their business, profession and personal transfer.

\section{Level of Satisfaction}

Researcher had developedeight variables to measure the level of satisfaction of Public Sector Bank's Mobile Application. i.e. (i) Security; (ii) User friendly ; (iii) Easy transfer ; (iv) Service charge ; (v) Linked with google pay (vi) Linked with Phone pe ; (vii) Linked with credit card and (viii) Support with mobile phone.Five point Likert scale designed by the researcher and has the score from the sample respondents. Mean and Standard deviation were calculated, i.e. 28.493 and 2.781 , with the mean and standard deviation, the satisfaction level is calculated. The below table presents the score and satisfaction level.

Table- 8 Low, medium and high satisfaction level

\begin{tabular}{|l|l|l|}
\hline Sl. No. & Score & Level \\
\hline 1 & Less than 25.712 & Low \\
\hline 2 & 25.712 to 31.274 & Medium \\
\hline 3 & Above 31.274 & High \\
\hline
\end{tabular}

Sources: Survey data

Thirty-seven respondent's total score 25.712, they are taken as low satisfaction level. The score between 25.712 and 31.274 were taken as medium satisfaction level and the score above 31.274 were taken as high satisfaction level.

Table - 9 Satisfaction level of Samples

\begin{tabular}{|l|l|l|}
\hline Satisfaction Level & Number of Respondents & \% \\
\hline Low & 37 & 17.05 \\
\hline Medium & 116 & 53.46 \\
\hline High & 64 & 29.49 \\
\hline & 217 & 100 \\
\hline
\end{tabular}

Sources: Survey data

Out of two hundred and seventeen samples,thirty-seven (17.05\%) respondents were felt low satisfaction level. One hundred and sixteen $(53.46 \%)$ respondents were felt medium satisfaction level and sixty-four respondents were felt high satisfaction level.

Table -10 Correlation - Relationship Personal Details and Satisfaction Level

\begin{tabular}{|l|l|l|r} 
Variable & Correction & P value & Result \\
\hline
\end{tabular}




\begin{tabular}{|l|l|l|l|}
\hline Agegroup & $0.913^{* *}$ & $0.001 \boldsymbol{i}$ & Positive \\
\hline Gender & 0.382 & $0.448 \boldsymbol{i}$ & - \\
\hline MaritalStatus & $0.847^{*}$ & $0.001 \boldsymbol{i}$ & Positive \\
\hline Family type & $-0.762^{*}$ & $0.005 \boldsymbol{i}$ & Negative \\
\hline Monthly Family Income & 0.442 & $0.225 \boldsymbol{i}$ & - \\
\hline Occupation & $0.698^{* *}$ & $0.001 \boldsymbol{i}$ & Positive \\
\hline Number of Bank account & $0.718^{*}$ & $0.001 \boldsymbol{i}$ & Positive \\
\hline
\end{tabular}

\section{Sources: Survey data}

Age group (0.913) and occupation (0.698) has positive and significant relationship with level of satisfaction at $1 \%$ significantlevel.

Marital status (0.847) and number of bank account (0.718) has positive and significant relationship with level of satisfaction at 5 per cent significant level.

Family type (-0.762) has significant and negative relationship with level of satisfaction at $i 5$ per cent significant level.

\section{Findings}

The age group of 41 years to 55 years old samples are the majority in this present study. Male samples are the majority $(61.29 \%)$ out of the gender male and female. The married samples are the majority (56.22\%) out of married and unmarried samples. The family type nuclear is the majority (65.90\%), which taken two categories i.e. nuclear and joint family type. The monthly family income between Rs. 60,001 and Rs. 90,000 is majority. Government sector's working samples are in majority. Majority (54.38\%) of the respondents are operating two bank accounts for their business, profession and personal transfer.Majority (53.46\%) of the respondents felt medium level of satisfaction.

\section{Suggestions}

The following suggestions presented by the researcher to the service providers and banks.

1. Customers are using google pay and phone pe to transfer money, because all the retailers are having QR code to receive money. This is convenient to the customers and retailers. Now-a-days many retailers not accepting the google pay because of network issues and server busy. So the retailers are advised the customer to swipe ATM cum Debit card. Bankers should develop effective QR code payment to their customers to transfer money safe and secure.

2. High denomination are also transferring by the users, but the money splitting in to small denomination and transferring to the receivers. The high denomination is transfer by banker's mobile application will be safer; the customers should be educated by the bankers to transfer through their mobile application.

3. Customers are in need of more secure for their money transfer, the bankers should assure them for their customer's money.

4. Mobile applications should update by the bankers periodically, more study should conduct by the bankers to find the customer's requirements. 


\section{Conclusion}

The researcher conducted the study in Coimbatore city to find the customer satisfaction of public sector bank's mobile application. 217 samples were taken for this study, adopted convenient sampling method. Data collection done direct data collection and online mode. Before issue the questionnaire the respondents were ensured that, they are having banking account and operating through banks mobile application. Public sector banks are also developing their own mobile application and it is safe. Many customers are having more than two bank account, they need single gateway to send and receive money, which is why customers prefer the common gateway. Many customers are using both google pay and or phone pe and bank's mobile application. Bank's mobile application is convenient to maintain the credit card outstanding and payment details. The satisfaction of bankers' mobile application is only medium level. Banks may conduct more study periodically to measure the level of utilization and satisfaction to improve the mobile application and satisfy their customers.

\section{References}

[1] Radwan Ali, Mike Gallivan, Seema Sangari (2019), A study on Mobile Apps in the Banking Industry, International Journal of Digital Society (IJDS), Volume 10, Issue 3, September 2019, pp. $1524-1533$.

[2] Uwalaka, Samuel C \& Dr. Peace Eze (2020), Effect of Mobile Banking On Customer Satisfaction in Commercial Banks In Anambra State, International Journal of Innovative Social Science \& Humanities Research, 8(1), Jan - Mar. 2020, pp. 101 - 109.

[3] Prof. Janmejay V. Shukla Co-Author: Dr. Dileep Kumar Singh (2020), A study of mobile banking $\&$ its impact on consumer satisfaction with reference to Nagpur Area, Journal of Engineering Technologies and Innovative Research (JETIR), Volume 7, Issue 8, pp. 648 - 652.

[4] Romario Gomachab and Bernardus Franco Maseke (2018), The impact of mobile banking on customer satisfaction: Commercial Banks of Namibia (Keetmanshoop), Journal of Internet Banking and Commerce, Volume 23, No. 2, June 2018, pp. 1 - 18. 